\title{
Foreign Affairs through Private Papers: Bishop Porfirii Uspenskii and His Jerusalem Archives, 1842-1860
}

\author{
Lora Gerd and Yann Potin
}

Jerusalem is now become a central point of interest to France and Russia. It is no doubt the object of Russia to subjugate the primitive churches of the countries. ${ }^{1}$

Since the Open Jerusalem project began, the documentation of the Russian presence in Jerusalem from 1840 onwards has posed major challenges for scholars. Access to archives both in and outside of Jerusalem has become increasingly difficult as Russia's strategic presence in the Middle East expands. The question we ask is: where in the Russian archives can scholars find material to explore the intimate relations between the Russian Orthodox Church, Russian imperial patronage, and the city of Jerusalem? The starting point for documentation and archival study in this area is the exploration of a private archive, preserved for more than a century in the collections of the Academy of Sciences of St. Petersburg, on the banks of the river Neva.

\section{The Russian Presence in Jerusalem and Its Official Records: Recent and Century-old Publications}

The pilgrimage to Jerusalem has played a central role in Russian Christianity since the nineteenth century, when messianic movements in the Orthodox church increased their emphasis on pilgrimage. The number of Russian pilgrims to Jerusalem each year during the nineteenth century was at least five times more than that of Catholic or Protestant pilgrims from Western Europe. Historians have highlighted this in order to demonstrate the strategic role it

1 The National Archives of the UK (TNA), Foreign Office (FO) 78/581, Letter from William Tanner Young, British Vice Consul in Jerusalem to Stratford Canning, Ambassador of the United Kingdom in Constantinople, January 8, 1844.

(C) LORA GERD AND YANN POTIN, 2018 | DOI:10.1163/9789004375741_008

This is an open access chapter distributed under the terms of the prevailing CC-BY-NC-ND License at the time of publication. 
played in the Eastern policy of the Tsarist Empire. ${ }^{2}$ By marking its presence in Jerusalem, the Russian Empire managed to penetrate the heart of its biggest rival, the Ottoman Empire. Since the eighteenth century, the Tsars carried out continuous attempts to erode Ottoman boundaries. While, until 1917, the Tsars continued to formally claim their rights to Constantinople, sending missionaries to Jerusalem was another form of diplomatic residence. In parallel, the latent competition between the Greeks and the Russians reflected ancient divisions within Orthodox Christianity. The Russian archives must therefore be examined along with the Greek archives in Jerusalem, Athens, and Istanbul. The Russian presence in Jerusalem grew steadily during the nineteenth century. As a result, from 1860 to 1872 , outside the walls of the Old City near the NotreDame-de-France hospital, a large hospice known as the Russian Compound was established. It could accommodate more than a thousand patients and pilgrims. It quickly became the nucleus of a Russian neighborhood. Today it is integrated in the old part of West Jerusalem, making it not only a part of the history of diplomacy, but also a symbol of urban development, further complicating the question of how the Russian archives were scattered. After 1917, the situation became even more complicated when the Soviet Union seemed to lose interest in the Russian presence in the Holy Land. The situation did not change until the post-1948 concession of the Russian compound to the state of Israel. The actual presence of the archives in the building, as well as their eventual location and preservation, is yet to be verified. A major Russian emigration to Palestine following internal schisms within the Russian Orthodox Church continued during the interwar period. Russian Jews making aliyah to Israel, particularly to Jerusalem, made up a large portion of Russian emigration to the Holy Land.

Since 1882, the Russian presence in Palestine has been inseparable from the activities of the Imperial Society of Palestine. The Society publishes a multiplicity of sources, both historiographical and apologetic. ${ }^{3}$ The revival and renewal of the activities of the Imperial Society in recent years is impressive, and has resulted in numerous reeditions and new collections of published sources. Over the past 20 years, Indrik publishers, run by Kirill Vakh, has edited a unique catalogue of inventories and documents. The last collection

2 See, for example, Lorraine de Meaux's recent La Russie et la tentation de l'Orient (Paris: Fayard, 2010), 278-91.

3 Elena Astafieva, "La Russie en Terre Sainte: le cas de la Société Impériale Orthodoxe de Palestine (1882-1917)," Cristianesimo nella storia 1 (2003). 
was published in 2017. It was prepared by Nikolai Lisovoi in collaboration with the (new) Imperial Society of Palestine. ${ }^{4}$

Until 1917, one of the main cultural and scientific activities of the society consisted of publishing sources and archival documents about the early years of the "Russian presence" in Jerusalem. ${ }^{5}$ Historiography retains 1843 as a founding date. The year corresponds to the secret mission carried out between December 1843 and August 1844 by Archimandrite Porfirii Uspenskii in Jerusalem. This was followed by a second mission between 1847 and 1854 . However, the Russian Ecclesiastical Mission in Jerusalem was only officially recognized in 1858, after the Crimean War. In 1865, the arrival of Antonin Kapustin at the head of this mission began an active period of initiative and sustainable investments that continued until the death of Kapustin in $1894 .{ }^{6}$

\section{The Academy of Sciences of St. Petersburg: An Archival Oasis}

The beginning of the Russian presence in Jerusalem is connected to the Russian mission's first leader, the prominent ecclesiastic Archimandrite (later Bishop) Porfirii Uspenskii (1804-85). ${ }^{7}$ Porfirii, whose secular name was Konstantin Alexandrovich Uspenskii, was born into the family of a church lector in the provincial town of Kostroma. After finishing the local church school $(1813-18)$, he studied in the Kostroma Theological Seminary (1818-24) and the St. Petersburg Theological Academy (1825-29). After graduating from the Academy, he took his monastic vows and was ordained deacon, and later priest. He started his career as a teacher in the Richelieu Lyceum in Odessa. In 1838, he was appointed rector to the Kherson Theological Seminary and in 1840 he was appointed priest to the Russian mission in Vienna. On November 14, 1842, the Russian Holy Synod sent Porfirii to Jerusalem to gather information about the life of the Orthodox Christians in Palestine and Syria. His first stay in Jerusalem lasted from December 20, 1843, to August 7, 1844. On July 31, 1847,

4 Nikolai. N. Lisovoi ed., Rossiia $v$ Sviatoi Zemle. Documenty i materialy [Russia in the Holy Land. Documents and materials] 2 vols. (Moscow: Indrik, 2017).

5 Derek Hopwood, The Russian Presence in Syria and Palestine, 1843-1914: Church and Politics in the Near East (Oxford: Clarendon Press, 1969).

6 Lucien J. Frary, "Russian Missions to the Orthodox East: Antonin Kapustin (1817-1894)," Russian History 40, no. 1 (2013).

7 Theophanis G. Stavrou, "Russian Interest in the Levant, 1843-1848: Porfirii Uspenskii and the Establishment of the First Russian Ecclesiastical Mission in Jerusalem," Middle East Journal 17 , nos. $1 / 2$ (1963). 
he was appointed chief of the first Russian Ecclesiastical Mission to Jerusalem, where he arrived in mid-February 1848 , and stayed until May 3, 1854, when he had to leave due to the outbreak of the Crimean War (1853-56). After the war, Porfirii was no longer head of the mission, but in 1860 , he visited Jerusalem a third and final time. During the years of Porfirii's stay in Jerusalem, he was involved in church and political activities. He was also engaged in intensive research work on the archeology and history of Palestine, Syria and Egypt. From this research, he gathered a substantial collection of manuscripts and books. At that time, his knowledge of the lives of the non-Muslim population of Jerusalem superseded that of any other Russian representative in the Christian East. The archives of Porfirii are now in good condition and are preserved in the St. Petersburg Department of the Archives of the Russian Academy of Sciences (fond 118). The Imperial Academy of Sciences acquired them after his death on April 19, 1885, as was stated in Porfirii's testament.

Porfirii left the Academy an endowment, the interest of which was bound to fund the publication of his scientific works. In 1886, two members of the Russian Imperial Academy, Bychkov and Bühler, reported on their preliminary work with the archives. At the same meeting of the Academy, it was decided that Polikhronii Syrku, a specialist in Byzantine and Old Slavonic studies, would endeavor to further systematize and describe Porfirii's archive. The outcome of this work was impressive. In 1891, a printed catalogue of Porfirii's papers appeared. ${ }^{8}$ Between 1894 and 1901, the Academy of Sciences published eight volumes of Porfirii's journals. ${ }^{9}$ Other important publications of the "Porfirii Commission" are two volumes of documents and official correspondence prepared by the Byzantine historian Pavel Bezobrazov. ${ }^{10}$ Several research studies on Porfirii's activities were carried out using both the published and unpublished archival material.11

Polikhronii Agapievich Syrku, ed., Opisanie bumag episkopa Porfiriia Uspenskogo pozhertvovannykh im v Imperatorkuiu Academiiu nauk po zaveshchaniiu [Description of the papers of Bishop Porfirii Uspenskii, left by him to the Imperial Academy of Sciences according to his testament] (St. Petersburg: Imperial Academy of Sciences, 1891).

Porfirii Uspenskii, Kniga bytiia moego. Dnevniki i avtobiograficheskie zapiski episkopa Porfiriia Uspenskogo [The book of my being: journals and autobiographical notes of Bishop Porfirii Uspenskii], 8 vols. (St. Petersburg: Imperial Academy of Sciences, 1894-1901).

10 Pavel V. Bezobrazov, ed., Materialy dl'a biographii episkopa Porfiriia Uspenskogo [Materials on the biography of Bishop Porfirii Uspenskii]. Vol. 1, Official Papers; Vol. 2, Correspondence (St. Petersburg: Imperial Academy of Sciences, 1910).

11 Alexei Afanas'evich Dmitrievskii, Ep. Porfirii Uspenskii kak iniciator i organizator pervoi russkoi dukhovnoi missii v Ierusalime [Bishop Porfirii Uspenskii, the initiator and 


\section{Between Inspection and Messianism: An Overlap between Official Documentation and Personal Papers}

The first set of documents, which concern Porfirii's appointment to Jerusalem, are the official papers of the Holy Synod and to the Russian Ministry of Foreign Affairs. ${ }^{12}$ Most of them are preserved in at least two copies - one or more in Porfirii's archive, and the other in the archive of the Holy Synod. A third copy can be found in the Ministry of Foreign Affairs. Among them are Porfirii's letters to the over-prosecutor [Ober-prokuror] of the Holy Synod, Count Nikolai Protasov (sixteen letters), and his letters to the directors of the departments of the synod, Serbinovich (eighty-five letters), Voitsekhovich (two letters) and Karasevskii (eight letters). ${ }^{13}$ The next file (number 45 ) also contains official letters written by Porfirii, which were addressed to the Russian Ambassador at Constantinople Vladimir Titov (seventy-four letters), and to the Asian department of the Ministry of Foreign Affairs. Many of them contain detailed reports on the state of affairs in the Near East. Dossiers 46 and 47 contain 143 letters from 1848 to 1853 written by Porfirii to the Russian Consul General at Beirut, Konstantin Basili. They also include one report about the Holy Sepulchre written for Emperor Nicolas I. The official answers from these individuals form a separate file (49). Another group of interesting letters were addressed to Porfirii by the Russian consuls in Jaffa (G. Mostras) and in Beirut (K. Basili, file 5o). Porfirii also corresponded with Boris Mansurov, the founder of the Palestine

organizer of the First Russian Ecclesiastical Mission in Jerusalem] (St. Petersburg, 1906); Dmitrievskii, Porfirii (Uspenskii). Po povodu stoletija so dnia ego rozhdenija [Porfirii (Uspenskii): on the occasion of the centenary of his birth] (St. Petersburg, 1906); Dmitrievskii, "Uchrezhdenie i pervyi period deiatel'nosti Russkoi Dukhovnoi missii pod nachal'stvom Arkhimandrita Porfiriia (1842-1855)" [Foundation and first period of the activities of the Russian ecclesiastical mission under archimandrite Porfirii (18421855)], in Rossiia v Sviatoi Zemle. Documenty i materialy, vol. II., ed. Nikolai N. Lisovoi, (Moscow, Mezhdunarodnye otnosheniia, 200o). The scholarship on Porfirii's materials has been mainly focused on his scientific research in church history and manuscripts. See Archimandrite Innokentii (Prosvirnin), "Pam'iati Episkopa Porfiriia (Konstantina Alexandrovicha Uspenskogo) 1804-1885" [In memory of Bishop Porfirii (Konstantin Alexandrovich Uspenskii)] Bogoslovskie Trudy 26 (1985); Lora A. Gerd, "Porfirii Uspenskii: iz epistoliarnogo naslediia" [Bishop Porfirii Uspenskii: from his epistolograpy], in Archivy Russkikh vizantinistov v Sankt-Peterburge [Archives of the Russian Byzantinologists in St. Petersburg], ed. Igor P. Medvedev (St. Petersburg: Dmitrii Bulanin, 1995), 8-21. 118, op. 1, d. 44 .

13 Ibid., d. 44. 
Committee. Most of the letters focus on Mount Athos, but one of them concerns the new head of the Russian mission in Jerusalem after the Crimean War, Bishop Kirill Naumov. Porfirii found the appointment of a Russian bishop to Jerusalem to be unfitting because the presence of two bishops in one town was against the church canons. Furthermore, Kirill Naumov's behavior was, in his opinion, "inappropriate." Among the letters written by Porfirii to Russian high ecclesiastics, his correspondence with Metropolitan Filaret (Drozdov) of Moscow is the most noteworthy. ${ }^{14}$

The papers of the Russian mission eo ipso are conserved in two large files (238 and 352ff.) containing official correspondence between Porfirii and different persons in Russia and abroad dating from 1842 to 1854 . Apart from letters written by Basili and Titov, the files also contain the mission's financial papers and an architectural plan for the house of the Russian mission, which was eventually built in 1853 . Porfirii wrote a summary of his activities in Jerusalem..$^{15}$ During his absence from Jerusalem, he was kept informed by his assistant and a member of the mission, Hieromonk Feofan (eight letters dated 1851-52). Information on Jerusalem is dispersed in all his private correspondence during his stay there. Nineteen letters were addressed to Greek high ecclesiastics; eleven of which were sent to Kyrillos II, the Patriarch of Jerusalem (1848-54, 40ff.). ${ }^{16}$

During his stay in Jerusalem, Porfirii wrote detailed notes on the history, geography, ethnography and statistics of Palestine. ${ }^{17}$ In a separate file he collected copies and translations of others' descriptions of the Holy Land as well as journals kept by pilgrims from different countries and centuries. ${ }^{18}$ Among the copies of documents written by others, the most important document is the printed report by Boris Mansurov (the founder of the Palestine Commission, dated 1858), written after his visit to Jerusalem. It was followed by a letter sent by Grand Duke Konstantin Nikolaevich to Porfirii, and Porfirii's response which outlined his opinion on Mansurov's proposals. ${ }^{19}$ Another note, which was also published later, belongs to Consul Basili and contains statistics relative to Syria and Palestine. ${ }^{20}$ Porfirii's collection is rich in illustrative

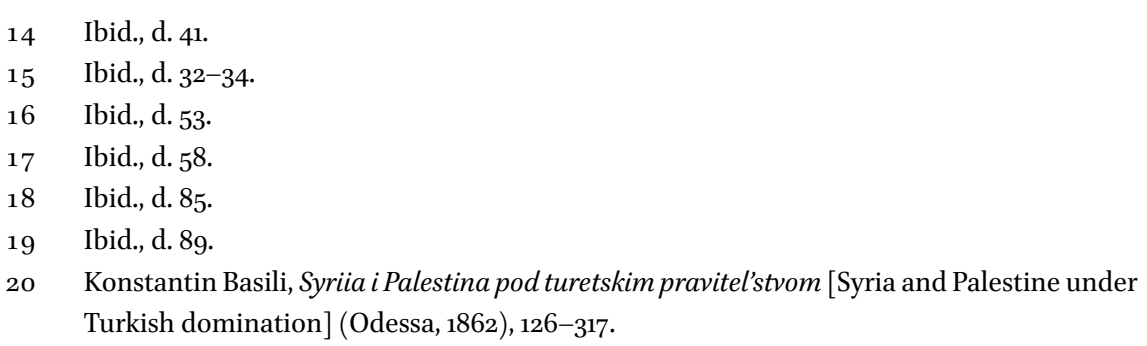


materials including engravings, sketches, drawings, and photos; seventy-six of them are related to the Holy Land and Jerusalem. ${ }^{21}$

The Russian Ecclesiastical Mission to Jerusalem was initially established to address two principal ideas. The first aim of the mission was to support Eastern Orthodoxy (both Greek and Arab) against Catholic and Protestant proselytism. The second aim was to offer aid and efficient organization to Russian pilgrimages to the Holy Land. These two aims are constantly emphasized in the majority of official and unofficial letters and notes, written between 1838 and $1842,{ }^{22}$ about the mission. On March 1, 1841, the over-prosecutor of the synod, Count Protasov, sent Emperor Nicolas I a note in which he highlighted the interests of the Russian pilgrims to the Holy Sepulchre, and the importance of providing a Russian church service for them. ${ }^{23}$ On June 13, 1842, the Minister of Foreign Affairs, Vice-Chancellor Count Nesselrode, wrote an extensive note encouraging a Russian ecclesiastical with wide-ranging functions to be sent to Jerusalem. Such an envoy could assist the Greek Orthodox clergy and the local Orthodox population. An envoy could also act as a link between the Patriarchate of Jerusalem and the Russian church. Moreover, he could gather necessary information for the Russian government. The envoy's mission would be to support Orthodoxy against Roman Catholicism and Protestantism, and to prevent the local Christians from leaving the church of their baptism. At the same time, the chosen person would have to travel independently of any official mission and would have the technical status of a mere pilgrim. ${ }^{24}$ The Vice-Chancellor's requests resulted in the appointment of Archimandrite Porfirii to the Russian mission in Jerusalem. According to the terms of his appointment, Porfirii could not interfere in any political affairs.

21 SPBFARAN, Fond 118, op. 1, d. 171, 174, 175, 191, 195. Most of the photographic views are published in Roman Gultiaev, ed., Ierusalim v 1857 godu v fotografiiakh iz kollektsii episkopa Porfiria (Uspenskogo) [Jerusalem in 1857 based on photos from the collection of Bishop Porfirii (Uspenskii)] (Moscow: Indrik, 2007).

22 See for example the note of Andrei Muraviev on the Monastery of the Cross near Jerusalem (1838) in Lisovoi, Rossiia v Sviatoi Zemle, 8; Konstantin Basili (consul in Beirut) to Andrei Muraviev, October 6/18, 1839 in Lisovoi, Rossiia $v$ Sviatoi Zemle, 9-11 and the report by Karl Nesselrode on the monasteries in Jerusalem where Russian pilgrims can stay (April 30, 1840) in Lisovoi, Rossiia v Sviatoi Zemle, 11-12.

23 Bezobrazov, Materialy dl'a biographii, vol. 1, 3-5.

24 Ibid., 5-8. A copy of this paper is preserved in: Russian State Historical Archives (in St. Petersburg) (Rossiiskii Gosudarstvennyi Istoricheskii Archiv, RGIA), fond 797, op. 11, II otd. 2 st., d. 28809. Most recent edition (following a copy from the Archives of Foreign Policy of the Russian Empire (AVPRI - Arkhiv Vneshnei Politiki Rossiiskoi Imperii), Moscow), Lisovoi, Rossiia v Sviatoi Zemle, 13-14. 
He was to act in coordination with the Russian consul in Beirut. He was responsible for ensuring the proper distribution of donations from Russia. ${ }^{25}$ The religious and political situation in Jerusalem during the 1840 s was complex. Working there as an individual with no official status in an ostensibly diplomatic capacity was challenging. Porfirii himself understood this well and ironically called himself a kataskopos (spy in Greek).

\section{Impressions and Reflections of Jerusalem in the Eye of a Learned Monk}

On December 20, 1843, Porfirii entered Jerusalem. He was greeted by a delegation of local monks who invited him to stay in the Patriarchate. Instead, he decided to live in St. Theodore Monastery, where the Russian pilgrims lived at that time. ${ }^{26}$ "I am spreading my network," he wrote on December 21; "The French consul, and me as if a consul." 27 Despite his incognito status, from his initial appearance in Jerusalem, Porfirii was regarded as a Russian resident, even though Russia had no consulate in Palestine at that time. ${ }^{28}$

After arriving in Jerusalem, he was too preoccupied to meet with the local high clergy, and to gather detailed information about the state of church affairs. During 1844, he traveled extensively in Palestine. He visited Bethlehem, Hebron, Nazareth and the monasteries of the desert. Everywhere he went, he met local ecclesiastics, and engaged in discussions with Catholics, Armenians, Greeks, and Greek Orthodox Arabs. The poverty of the Greek Orthodox Arabs struck him, especially in contrast to the wealth of the bishops of the Brotherhood of the Holy Sepulchre. ${ }^{29}$ He had serious discussions with the Armenian Patriarch in Jerusalem, who expressed his concerns about both Greeks and Catholics. He expressed hope to receive assistance from the future Russian mission. Porfirii became a friend of the Metropolitan of Bethlehem, Dionysios. The pages of his journals contain rich information on

25 Bezobrazov, Materialy dl'a biographii, vol. 1, 20-24.

26 Porfirii Uspenskii, Kniga bytiia moego, vol. 1, 353.

27 Ibid., 354.

28 See Mironenko-Marenkova and Vakh's chapter, “An Institution, Its People and Its Documents: The Russian Consulate in Jerusalem through the Foreign Policy Archive of the Russian Empire, 1858-1914," in this volume.

29 See Dalachanis and Tselikas' chapter, "The Brotherhood, the City and the Land: Patriarchal Archives and Scales of Analysis of Greek Orthodox Jerusalem in the Late Ottoman and Mandate Periods" in this volume. 
the ethnography, local customs, history and archaeology of Jerusalem and Palestine. From July 22 to August 3, 1844, he carried out research on the monasteries of Jerusalem and the library of the Greek Orthodox Patriarchate. ${ }^{30}$ In December 1844, in Constantinople, he attended the funeral of the Patriarch of Jerusalem, Athanasios. During his stay, he gathered additional information concerning the administration of the Orthodox Patriarchal See of Jerusalem, the elections of the Patriarch, and the role of Russian diplomacy. Later he was interviewed on these matters by the Metropolitan of Moscow, Filaret, an integral figure in the foreign policy of the Russian Church in the nineteenth century. According to Porfirii, the Ecumenical Patriarchate of Constantinople pretended to manage the finances of the See of Jerusalem and to appoint the high clergy there. The Russian Embassy interfered immediately, demanding to control the distribution of donations from Russia to the Holy Sepulchre Brotherhood.

The observations Porfirii made during his first stay in Palestine resulted in several extensive reports written in Constantinople during SeptemberDecember 1844, that were sent to Titov, the Russian ambassador. The first report is called "Historical note about the Arab Catholics, or Units, in Syria and Palestine" (September 5-6, 1844, Constantinople). ${ }^{31}$ From as early as 1737, Porfirii reported on Rome's efforts in order to encourage unity among the Arabs from Aleppo, Damascus, and Lebanon. The Jesuits and Armenian Catholics were also included in these efforts. He also gave a brief update on the Armenian Catholics in Palestine in the nineteenth century, reporting on the protection they enjoyed from the French consul. On October 28, 1844, Porfirii presented Ambassador Titov with a detailed note, dated October 12, on the state of the Orthodox church of Jerusalem. ${ }^{32}$

In the note, he addresses the main problems with the Greek Orthodox Patriarchate of Jerusalem. He criticized the Patriarch for living in Istanbul, rather than in Jerusalem. Furthermore, he pointed out that the Greek clergy was poorly educated and neglected the Arab clergy. According to the bishop, the Arab clergy were extremely poor and possessed little education or enlightenment. The second part of Porfirii's note focused on the Catholic mission and its success among the Orthodox population, while the third part discussed the Protestant, mainly Anglican mission. Porfirii then proposed methods of supporting Orthodoxy in Jerusalem and throughout Palestine. The suggested measures concerned the organization of regular school education,

\footnotetext{
$30 \quad$ Porfirii Uspenskii, Kniga bytiia moego, vol. 2, 309-38.

31 Bezobrazov, Materialy dl'a biographii, vol. 1, 34-50.

$3^{2}$ Ibid., 51-96.
} 
hospitals, and an old-age home in Jerusalem. Such establishments would not only benefit the Greeks, but also the Arabs. Finally, he presented the ecclesiastical and financial aims of the future Russian mission in Jerusalem. On the same day, Porfirii sent Titov a detailed historical essay and a description of the present state of the holy sites in Jerusalem, including statistical data on the incomes and expenses of the Temple of the Holy Sepulchre, and other important places of veneration. ${ }^{33}$ On December 3, 1844, Titov forwarded Porfirii a note written in French that had been sent to him a few months earlier by Zachariah, the Armenian Patriarch in Jerusalem. The note discussed the properties and rights of the Armenians in Jerusalem. Porfirii responded by expressing his opinion on these matters. ${ }^{34}$ His critical notes concern the historical data presented by the Armenian Patriarch (on the Christianity of the wife of King Abgar, the omission of the period between the Council of Chalcedon and Saladin's time, etc.). Porfirii was uncertain about the legal force of Saladin's firmans, but was inclined to support Zachariah's claim to the property on Mount of Olives, which had been purchased by the Armenians in 1836, and expropriated by the Catholics and Greeks in 1839. Porfirii believed the best solution was to build a church where all Christian groups could hold their own individual liturgical services.

By 1845 , the Russian mission had largely been planned. On January 6, Porfirii sent Titov a detailed plan of the mission's structure along with the aims and functions of each member. In order to avoid political suspicions, the status of the mission was still semiofficial. It was called "a pilgrimage monastery," and its members were appointed for seven years. According to the instruction on his appointment, Porfirii should have begun negotiations with the Greek Orthodox Patriarch of Jerusalem by August 28, 1847. The purpose of the negotiations was to encourage the Greek Orthodox Patriarch to agree to provide an occasional divine liturgy in Slavonic for the Russian pilgrims, as well as to educate Greek and Arab boys. The members of the mission brought official recommendation letters from the Russian Holy Synod, addressed to the Patriarch of Jerusalem. ${ }^{35}$ Before leaving for Jerusalem, Porfirii requested permission from the administration of the Holy Synod for two young Arabs to study icon painting in the St. Petersburg Theological seminary. He also requested that Russian ecclesiastical books be sold in Jerusalem for Bulgarian and Serbian pilgrims. Both requests were approved. On October 14, Porfirii left St. Petersburg

\footnotetext{
33 Ibid., $96-128$.

34 Ibid., $128-37,138-45$.

35 Ibid., 146-6o. The main contest of the report is repeated by Porfirii in his journals.
} 
for the Holy Land. On arriving in Jerusalem, he had a meeting with the new Greek Orthodox Patriarch of Jerusalem, Kyrillos II, who had been elected on March 28, 1845. They discussed the relations between the Orthodox and Armenian clergy and the Latin Catholics. In a few days, Porfirii and his three companions (Hieromonk Feofan Govorov and two students of St. Petersburg Theological Academy, Soloviev and Krylov) settled in the Monastery of the Archangels, and lived there until the beginning of 1854 .

\section{Uspenskii in the Report: Imperial Foundation Disguised?}

On June 6,1847 , Porfirii wrote a note outlining the organization and structure of the mission, addressed to K. Serbinovich, the director of the office of the Holy Synod. ${ }^{36}$ He gave a detailed account on the material life of the members of the mission. He discussed their needs, taking into attention the local peculiarities of Jerusalem. A financial note and an account of the expenses, including the salaries of the members, follow the list of items.

In a document dated January 19, 1848, but obviously finished later, Porfirii wrote an extensive report to Ambassador Titov regarding the state of affairs of the church of Palestine. ${ }^{37}$ He details the position of Patriarch Kyrillos II and the opposition party, which planned to replace him with the Metropolitan of Tabor, Ierotheos. Then he reported in brief on the conflicts between Latins and Orthodox in Bethlehem and discussed the Ottoman government's attempts to pacify the Christian confessions. He then reports on the appointment of Giuseppe Valerga, the Latin Patriarch at Jerusalem, and on the state of Catholicism in Palestine. Finally, he discusses Protestant activities and Bishop Samuel Gobat's attempts to Christianize the Jews. ${ }^{38}$ Porfirii's notes contain details on the contemporary situation, including confidential information about the internal dynamics of the Greek Orthodox Church. Special attention is paid to the missionary activities of Gobat, consecrated in 1846 as the second Anglican bishop in Jerusalem, and to his plans to convert both the Eastern Christians and the Jews to the Anglican church. Porfirii also commented on the problematic relationship between Gobat and the British authorities in the United Kingdom.

$\begin{array}{ll}36 & \text { Ibid., 261-67. } \\ 37 & \text { Ibid., 277-84. } \\ 38 & \text { Ibid., 284-85. }\end{array}$ 
The next report to Titov, dated October 4, 1848, concerns the economic aspects of the mission and the restoration of the monastery where Porfirii and his companions lived. ${ }^{39}$ It also touches upon the Holy Synod report of February $11,1849 .{ }^{40}$ Three months later, Porfirii wrote a note about the Russian pilgrims in Palestine and sent it to Basili, the consul in Beirut. ${ }^{41}$ In it, he described the urgent need to improve the poor living conditions of the pilgrims. This included plans to reorganize a permanent medical service for the pilgrims in the Archangels Monastery. The next step would address their spiritual interests. According to Porfirii, this would be the responsibility of the members of the mission. The report is followed by a list of additional expenses that needed to be covered. On November 15, 1849, Porfirii informed Titov of the needs of the Orthodox population in Palestine, which included church vessels, vestments, icons, Arabic books, and money for the poor. ${ }^{42}$ He requested an annual sum of a thousand rubles to meet these demands.

One of the main topics that were further discussed with Patriarch Kyrillos II concerned the property of the Holy Sepulchre in the Danube Principalities. Since the seventeenth century, about a quarter of the lands in Moldavia and Wallachia had been granted to the Eastern Orthodox churches and to a number of monasteries (including Sinai and Mount Athos). The earnings from these properties made up the main source of income for the Orthodox churches under Ottoman domination. After the Russo-Ottoman War of 182829, the local princes threatened to secularize these wastelands. The Russian government, which considered itself as the official protector of Orthodoxy in the Ottoman Empire, consistently stopped all attempts to reduce the rights of the church owners. Only after the Crimean War of $1853^{-56}$ did secularization become possible. ${ }^{43}$

In January 1851, Blondel, the Belgian minister at Constantinople, visited Jerusalem with the intention of restoring the tombs of the two famous Crusader kings, Baldwin and Gottfried. In a long discussion with Blondel and the Austrian consul, Porfirii tried to explain how complicated this endeavor

\footnotetext{
39 Ibid., $285^{-86 .}$

$40 \quad$ Ibid., $286-87$.

41 Ibid., $323-28$.

42 Ibid., 331-36. See also the report from November 30 on the printing of Arab church books (ibid., 336-37).

43 See Lora A. Gerd, "Sekuliarizatsiia imenii vostochnykh monastyrei I tserkvei v Valakhii I Moldavii v nachale $1860-$ kh godov I Rossia" [Secularization of the properties of the eastern monasteries and churches in Walachia and Moldavia in the beginning of 1860 and Russia], Vestnik pravoslavnogo Sviato-Tichonovskogo Gumanitarnogo universiteta 6, no. 61 (2004).
} 
would be. Meanwhile, he conveyed his position on the church and national situation at the holy sites. In Porfirii's view, the holy sites belonged to all Christians, and all Orthodox peoples had equal rights as their keepers. The restoration of these tombs would have provoked jealousy and indignation from the Ottoman authorities and different Christian confessions. ${ }^{44}$

After the publication of the Hatt-l S Serîf of Gülhane in 1839 and the transformation of the administrative system of the Ottoman Empire, church reforms were planned. ${ }^{45}$ One of them was the introduction of a regular salary for the high Orthodox bishops. During his visit to Jerusalem in September 1851, the Patriarch of Alexandria, Ierotheos, discussed these reforms with Porfirii, who stressed that these measures might be harmful for the church. ${ }^{46}$ Metropolitan Filaret later developed the same ideas about the second stage of Tanzimat in the late $185 \mathrm{os}^{47}$ Porfirii was also opposed to reducing the number of the bishoprics of the Orthodox Church in the East. In his opinion, this measure would weaken the church and create opportunities for Western missionaries.

After a short journey to Russia at the end of 1851 , Porfirii focused on the restoration of the dome of the Holy Sepulchre and ensured the participation of Russia and France in the project. ${ }^{48}$ During a series of discussions with Russian diplomats and Greek clergymen, he proposed that, as an initial step, the Russian government should rent the upper floor and the roof of the temple, then inhabited by a family of noble Muslims. ${ }^{49} \mathrm{He}$ continued his mediation in family affairs of the Greek Orthodox Arabs and Greek clergy as well, trying

44 Uspenskii, Kniga bytiia moego, vol. 4, 80-83.

45 See Dimitrios Stamatopoulos, Metarrythmisi kai ekkosmikefsi. Pros mia anasynthesi tis istorias tou Oikomenikou Patriarcheiou [Reforms and secularization: towards a reconstruction of the history of the Ecumenical Patriarchate] (Athens: Alexandria, 2003), 37-45.

46 Uspenskii, Kniga bytiia moego, vol. 4, 132.

47 Sobranie mnenii I otzyvov Filareta, mitropolita Moscovskogo i Kolomenskogo, po delam Pravoslavnoi tserkvi na Vostoke [A collection of the opinions and relations of Filaret, Metropolitan of Moscow and Kolomna, on the affairs of the Eastern Orthodox Church] (St. Petersburg: Synod Print, 1886), especially 1-14.

48 The realization of this project came only after the Crimean War. See Oleg Viktorovich Anisimov, Rossiia i Napoleon III: bor'ba za Sviatye Mesta Palestiny [Russia and Napoleon III: the struggle for the holy sites of Palestine] (Moscow: Indrik, 2014).

49 Besides the journals, very informative on the question of the dome is Porfirii's note from October 31, $185^{0}$ addressed to Consul Konstantin Basili (Bezobrazov, Materialy dl'a biographii, vol. 1, 338-47). Here he expressed his ideas on purchase of the whole house for 50,000 rubles and its reconstruction for the Russian mission for another 50,000. 
to support Arab priests and parishes when possible. ${ }^{50}$ Once more, he proposed to try and pacify relations among Christian confessions in Jerusalem. According to Porfirii's proposal, none of the three (Orthodox, Catholics or Armenians) would perform their liturgy in the temple, but they would go there for prayer.

From $185^{2}$ on, Porfirii was busy with the construction of the building for the Russian mission. On April 16, 1852, he addressed a note to the Russian chargé d'affaires in Constantinople, A. Ozerov, about this project. In it, he provided details about the funding of the construction by Patriarch Kyrillos II and about the Russian obligations in the project. ${ }^{51}$ Porfirii's archives contain several unpublished plans of the area and designs for the future building. ${ }^{2}$ Moreover, it appears that the reorganization of the Patriarchal school at the Holy Cross Monastery in Jerusalem and the foundation of an Arab printing house under Porfirii's direction were significant events in the early 185 os. $^{53}$ According to Porfirii's account, the printing house was organized in St. Nicolas Monastery under the typographer Lazaridis. The machines and the letters (both Greek and Arabic) were acquired in Paris, and the printing house was supposed to produce all liturgical books. Patriarch Kyrillos II appointed Porfirii as supervisor of the schools and the printing house.

After a short stay in Jerusalem in January-May 1854, Porfirii and the members of his mission, followed by some Russian pilgrims, had to leave Jerusalem. The beginning of the year had been marked for Porfirii by the conflict between the Latin Patriarch Valerga and the Orthodox inhabitants of the village of Beit Jala. On the French consul's demand, the Ottoman authorities imprisoned the inhabitants. Porfirii could not defend them openly, and expressed his sympathy only by sending them food at Easter. ${ }^{54}$

On the whole, the activities of the First Russian mission to Jerusalem were rather limited. Almost all of Porfirii's initiatives were paralyzed by the cautiousness of the Russian Ministry of Foreign Affairs and the international context. This institution can hardly be compared to the large-scale Russian activities

\footnotetext{
50 Bezobrazov, Materialy dl'a biographii, vol. 1, 338-47.

$5^{1}$ Ibid., $35^{6-59 .}$

$5^{2}$ SpbFARAN, fol. 118, op. 1, d. 33, fols. 179-83.

53 See Porfirii's report to A. Ozerov, November 15, 1852. Bezobrazov, Materialy dl'a biographii, vol. 1, 361-70.

54 Uspenskii, Kniga bytiia moego, vol. 4, 174-216. Details of the conflict are described by Porfirii in the report to the Asian department of the Ministry of Foreign Affairs, dated January 30, 1854. Bezobrazov, Materialy dl'a biographii, vol. 1, 376-429. This paper is in fact a general observation of Porfirii's activities in Palestine, beginning with his appointment and arrival in Jerusalem.
} 
that took place in the second half of the nineteenth century. Putting aside the major research work carried out by the members of the mission, the only essential result of its work was Porfirii's participation in the educational projects of Jerusalem Patriarch Kyrillos II.

\section{The Legacy of the Archimandrite Scholar and Its Unpublished Part}

After the Crimean War, Porfirii was no longer appointed to Jerusalem. He devoted the rest of his life to his research on the archival material, mainly manuscripts, that he brought to Russia from the Near East and the Balkans. After his time in Jerusalem, he was ordained bishop in Kiev, and later lived in Moscow. Nevertheless, his opinion as an expert on Palestine continued to be solicited. On January 6, 1858, following a request from Grand Duke Konstantin Nikolaevich, Porfirii responded to a proposal by Boris Mansurov, the future chief of the Palestine Committee, on the subject of organizing support for Russian pilgrims. ${ }^{55}$ Porfirii pointed out the necessity of establishing a Russian consulate at Jerusalem so that Russian pilgrims would be protected and helped. His view on the Russian donations to the Greek church in Jerusalem diverged strongly from that of the Foreign ministry. In Porfirii's eyes, Russia had no business concerning itself with the uses made of donations. The increasing number of pilgrims was a far more important concern. On the whole, Porfirii highly appreciated Patriarch Kyrillos' behavior towards the Russians and bitterly accused the Russian government for lack of support during his stay in Jerusalem in 1847-54. According to Porfirii's observations, the activities of the Western missionaries did not prove to be particularly threatening for Orthodoxy in Palestine. Even if Arabs converted to Catholicism or Protestantism, they quickly returned to the Orthodox Church in most cases. Porfirii advised the Russian authorities to use the Palestinian Jews of Russian origin to receive information. Finally, instead of placing a Russian missionary among the Orthodox population of Palestine, he proposed delegating an apokrisiarios (a permanent representative of the Russian church at the Patriarchate of Jerusalem). ${ }^{56}$

55 Bezobrazov, Materialy dl'a biographii, vol. 1, 429-68.

$5^{6}$ The restoration of the ancient church tradition of apokrisiarioi was discussed many times by prominent Russian and Greek ecclesiastics during the nineteenth century (Archimandrite Antonin Kapustin, Patriarch of Constantinople Ioakeim III, etc.). It was also under discussion in the Russian Holy Synod. Nevertheless, the subject always 
Porfirii's last visit to the Holy Land was from February 16, to July 23, 1860. Upon arriving in Jerusalem, after finding that his private belongings were safe, he went to visit old friends from the Greek clergy. Most of his time was spent on his research on the manuscripts, icons, and architecture of the Monastery of St. Sabbas, the basilica in Bethlehem, and the Monastery of the Holy Cross in Jerusalem. A number of sketches of these sites were made and later included by Porfirii in the text of his journals. He met European and Russian diplomats as well, but did not discuss political matters. His comments on the new leader of the Russian ecclesiastical mission bishop, Kirill Naumov, are quite critical. Naumov would, incidentally, soon be called back to Russia. ${ }^{57}$ During this final stay, Porfirii wrote four reports, addressed to the over-prosecutor of the Holy Synod, A. P. Tolstoi. The reports focused on the end of his stay in Jerusalem and his future service in Russia.

Two large files with documents, both published and unpublished, on the first Russian mission to Jerusalem are preserved at the Archives of the Holy Synod in St. Petersburg. ${ }^{58}$ There, one finds official reports from Porfirii to the synod recounting his arrival in Jerusalem, his move into the Archangels Monastery in 1848 , and the restoration of the rooms of the monastery. The Russian Synod rewarded Kyrillos' hospitality to the mission: instead of an annual sum of 300 Russian rubles rent, he received 700 rubles beginning in 1849. ${ }^{59}$ Many of the papers in the files concern financial matters, the appointment of new members, and a translator, Fadlala Saruf. ${ }^{60}$ Other papers include details on Porfirii's research journeys to Egypt and Sinai, his departure to Russia, and return trip to Jerusalem in $185^{1-52}$. A common topic of discussion was the construction of the new Mission building. Subjects on this topic included the Russian government's funding of the construction and budget required by the project. Patriarch Kyrillos II financed the initial construction, but the Russian Synod planned to cover all the expenses (12,00o rubles) over the course of four years. The synod's assumption was that the land and

managed to get buried in the paper routine of the ultraconservative and cautious governmental and church institutions, and the idea never became reality.

57 Uspenskii, Kniga bytiia moego, vol. 7, 225-75.

$5^{8}$ RGIA, fond 797 (Chancellery of the over-prosecutor of the Synod), op. 11, 2nd dept., 2d bureau, files 356 a and $\mathrm{b}$.

59 RGIA, K. Nesselrode to A. Protasov, December 7, 1848. Ibid., fols. 189-89v.

6o RGIA, Correspondence on the expenses of the mission (1850). Ibid., fols. 244-49v. Note by Porfirii on the appointment of new members of the mission, October 31,1851 , fols. $288-89$. 
building would become Russian property. ${ }^{61}$ In a letter, Porfirii informed overprosecutor Protasov about the Patriarch's invitation to become a curator of the Orthodox schools in Palestine. ${ }^{62}$

Porfirii's presence in Jerusalem was highly appreciated by the Ministry of Foreign Affairs, especially in the early 1850 s, when questions arose about the holy sites in Palestine. ${ }^{63}$ Several letters to the officials of the synod deal with the beginning of the war with Turkey in 1853 , the danger of further stay in Jerusalem, and a possible move to Beirut or Greece. ${ }^{64}$ Finally, official documents on the closing of the mission and discontinued funding are preserved in the same dossier. ${ }^{65}$ Many letters and reports from this file are originals, while some copies can be found in the Ministry of Foreign Affairs archives and in Porfirii's personal archives.

\section{Conclusion}

The value of Porfirii's archives was recognized long before the revolution of 1917. This serves to explain why special efforts were undertaken to publish them. The question we ask now is whether these publications cover his entire legacy. The journals published by Polikhronii Syrku contain not only the text of his notebooks, combined and ordered from different files, but his sketches and drawings as well. Nevertheless, a comparison with the archives themselves shows that the occasionally unpublished original letters written by others are filed to his handwritten journals. Even more gaps and additional data can be found in the publication of the correspondence and official papers. For example, all financial reports of the mission, as well as numerous letters on its economics and organization, remain unpublished. Through its systematic inventory work, the Open Jerusalem project is able to deliver a retroactive reconstitution of the Porfirii Uspenskii fonds through published and,

61 RGIA, K. Nesselrode to A. Protasov, January 30, 1850. Ibid., fols. 229-30; further correspondence, fols. 252-59. L. Seniavin to A. Protasov (on an expertise in situ whether the construction of a new house was really needed, October 10, 1859), ibid., fols. 268-69. Extract from the decision of the synod about the building of a new house (August 13, 1852, ibid., fol. 338), etc.

62 RGIA, Porfirii to Protasov, October 9, 1852. Ibid., fols. 349-49v.

63 RGIA, L. Seniavin to A. Protasov, September 10, 1852. Ibid., fol. 342.

64 RGIA, Porfirii to Serbinovich, ibid., fols. $385^{-86 v}$.

65 RGIA, Extract from the decision of the Holy Synod, December 22/31, 1854. Ibid., fols. 389-9o. 
in some cases, online documentation. As such, it is now possible to distinguish diplomatic from personal papers without obscuring the close and necessary interweaving between them. Even though he appears as one of the bestdocumented actors in Russian "Oriental" history in the nineteenth century, Porfirii deserves further attention. Previous publications of source texts do not preclude later publications of other texts once considered unimportant or marginal. The initial publication of Porfirii's archives obscured some of the material context of the documents and failed to reveal the variety of the sources from which the documents were derived. In so doing, personal, collective, and state archives were amalgamated and confused, and the result was a monumental publication meant to memorialize rather than to reveal complexity. Instead of calling upon the mutual critical efforts of historians and archivists, this editorial strategy sought to contribute to a political and religious hagiography. The many large-scale publication projects dedicated to Porfirii's "missionary" work reveal how his personal papers have been politically and nationally instrumentalized throughout time. Such projects, essentially trivial, lend particular urgency to the archival work of the Open Jerusalem initiative and justify the systematic revisiting of the contexts and logics that guided past archival and editorial work on the "Russian presence" in Palestine before 1917. 